\title{
High variability of chloroplast DNA in three Mediterranean evergreen oaks indicates complex evolutionary history
}

\author{
P Jiménez ${ }^{1}$, U López de Heredia ${ }^{1}, \mathrm{C} \mathrm{Collada}^{2}, \mathrm{Z} \mathrm{Lorenzo}^{1}$ and L Gil ${ }^{1}$ \\ ${ }^{1}$ Unidad de Anatomía, Fisiología y Genética, ETSI Montes, Universidad Politécnica de Madrid, Ciudad Universitaria s/n, 28040 Madrid, \\ Spain; ${ }^{2}$ Departamento de Biotecnología, ETSI Montes, Universidad Politécnica de Madrid, Ciudad Universitaria s/n, 28040 Madrid, \\ Spain
}

Chloroplast DNA variation was studied in three evergreen Quercus species ( $Q$. suber L., $Q$. ilex L. and $Q$. coccifera L.) from the Western Mediterranean Basin using PCR-RFLP. We studied five primer pair/enzyme combinations, four of them previously used in other European Quercus, obtaining a large number of haplotypes (81) grouped in three main types (suber type, ilex-coccifera I type and ilex-coccifera II type). Such level of haplotype diversity is higher than previously reported for the genus. Remarkable differences in haplotype richness between species have been found.
$Q$. ilex and $Q$. coccifera usually share the same haplotypes, while a number of $Q$. suber populations possesses variants of the ilex-coccifera I type. This fact is interpreted as a result of genetic introgression between $Q$. suber and $Q$. ilex. Reproductive factors that could determine this exchange are discussed, as well as the influence of different species histories on the present structure of evergreen Quercus in the Western Mediterranean Basin.

Heredity (2004) 93, 510-515. doi:10.1038/sj.hdy.6800551

Published online 25 August 2004

Keywords: Evergreen Quercus; cpDNA; introgression; diversity

\section{Introduction}

Mediterranean evergreen Quercus species are a group with overlapping habitats, which often leads to their consideration as an homogeneous entity in botanical, biogeographical or paleohistorical studies. In the Western Mediterranean Basin, Q. ilex (holm oak), Q. suber (cork oak), and $Q$. coccifera (kermes oak) are the dominant broadleaved species. The three species are sympatric in many areas, but some differences in their ecological requirements produce distinct responses to environmental conditions and hence different evolutionary histories. Previous studies have shown differences in their genetic variation patterns at both nuclear and cytoplasmic levels (Michaud et al, 1995; Toumi and Lumaret, 1998, 2001; Manos et al, 1999; Belahbib et al, 2001; Lumaret et al, 2002).

Most studies on genetic variation of forest trees have been carried out using nuclear markers. The chloroplast genome typically shows low intraspecific variation, although in the last decade, the development of new markers has allowed the detection of enough variation to assess phylogeographic patterns. Many such studies in Quercus species have used the PCR-RFLP technique (Whittemore and Schaal, 1991; Ferris et al, 1993; Petit et al, 2002; Olalde et al, 2002), producing a large amount of work in different species with a similar methodology,

Correspondence: L Gil, Unidad de Anatomía, Fisiología y Genética, ETSI Montes, Universidad Politécnica de Madrid s/n, 28040 Madrid, Spain. E-mail: lgil@montes.upm.es

Received 21 October 2003; accepted 11 June 2004; published online 25 August 2004 which allows comparison between studies. Although cpDNA diversity has been studied in $Q$. ilex and $Q$. suber (Belahbib et al, 2001; Lumaret et al, 2002), no work has been published to date on $Q$. coccifera.

The present work investigates the cytoplasmic variation of the sclerophyllous Quercus species in the Western Mediterranean Basin and the relationships among species. This report focuses on the description and comparison of PCR-RFLP patterns for $Q$. suber, $Q$. ilex and $Q$. coccifera, discussing possible causes for the differences found.

\section{Material and methods}

A total of 2313 individuals of $Q$. ilex (1118, 121 populations), Q. suber (859, 90 populations) and $Q$. coccifera (401, 46 populations) covering the Western Mediterranean range was sampled (Table 1). The sampling was more intense in the Iberian Peninsula than in other regions. In each stand, adult leaves were collected from 5 to 10 nonadjacent trees per species (mean $=9.2$ ). The DNA was extracted using a modified protocol of Doyle and Doyle (1990) following Dumolin et al (1995).

We used five pairs of primers to amplify the following chloroplast fragments: trnC[tRNA-Cys(GCA)]$\operatorname{trnD}[\mathrm{tRNA}-\mathrm{Asp}(\mathrm{GUC})]$ (CD), $\operatorname{trnT}$ [tRNA-Thr(GUG)]$\operatorname{trnF[tRNA-Phe(UGU)]~(TF),~} \operatorname{trnD[tRNA-Asp(GUC)]-~}$ trnT[tRNA-Thr(GGU)] (DT), psaA[PSI (P700 apoproteine A1)]-trnS[tRNA-Ser(GGA)] (AS) and trnS[tRNA-Ser(GCU)]-trnR[tRNA-Arg(UCU)] (SR) (Taberlet et al, 1991; Demesure et al, 1995: Dumolin-Lapègue et al, 1997a; Grivet et al, 2001). Each amplified fragment was digested 
with one restriction enzyme to avoid the risk of counting the same mutation twice (Dumolin-Lapègue et al, 1997b). Table 2 shows PCR conditions and the enzymes used. Digestion products were separated by electrophoresis in $8 \%$ polyacrylamide gels $(18 \times 24 \mathrm{~cm})$ using Tris-borateEDTA buffer $1 \times$ at $500 \mathrm{~V}$ for $240 \mathrm{~min}$. Fragments were revealed with a silver staining method in order to check polymorphisms. Fragment sizes were estimated using a 1 $\mathrm{kb}$ ladder (Gibco).

Data were scored as multistate characters as in Dumolin-Lapègue et al (1997b) and Petit et al (1997): each polymorphic restriction fragment is considered a character and the states are the different sizes of this fragment. The length variants were noted from 1 to 6,9 and 0 being reserved for restriction site mutations (9 means the appearance of a new restriction point and, consequently, two new bands instead of the expected one; and 0 the disappearance of a restriction point implying a new band with size equal to the sum of two missing bands). The numbers increase from the highest to the lowest molecular weight fragments to ease the notation, but this does not imply any mutational sequence.

Each individual's haplotype was a combination of the variants present in each restriction fragment for the five cpDNA amplified regions. A matrix of mutational differences between haplotypes was calculated to produce a minimum length spanning network of haplotypes using the $\mathrm{R}$ Ape 1.0 package (Paradis et al, 2003). This method is used as an alternative to Wagner parsimony analysis to connect the haplotypes by direct links having the smallest possible length (Prim, 1957), but conveys better the relationships between haplotypes (Excoffier and Smouse, 1994). Nodes of the network represent the haplotypes, while length of the branches is proportional to the number of mutations between them (Prim, 1957).

Table 1 Number of populations sampled in each country and species

\begin{tabular}{lccc}
\hline & Q. ilex & Q. suber & Q. coccifera \\
\hline Spain & 96 & 61 & 35 \\
Portugal & 2 & 10 & 3 \\
$\begin{array}{l}\text { France } \\
\quad \text { Continental }\end{array}$ & 10 & 2 & 8 \\
$\quad$ Corsica & 5 & 1 & - \\
$\begin{array}{l}\text { Italy } \\
\quad \text { Peninsula }\end{array}$ & 1 & 2 & - \\
$\quad$ Sardinia & - & 2 & - \\
$\quad$ Sicily & 3 & 3 & - \\
Malta & 4 & - & - \\
Tunisia & - & 1 & - \\
Algeria & - & 6 & - \\
Morocco & - & 90 & 46 \\
Total & 121 & & \\
\hline
\end{tabular}

\section{Results}

The polymorphic fragments and the size of the variants are indicated in Table 3. A total of 23 polymorphic regions with consistent and repeatable variation have been scored. The number of variants for each polymorphic fragment ranged between 2 and 6, most of them being length variants derived from insertion-deletions, except for five mutations involving recognition points. The most variable fragments for the three species are SR and AS, two regions in which microsatellite regions have been described in white oaks (Grivet et al, 2001). Another variable fragment, DT, also bears at least five (A)n repeats in both white (Deguilloux et al, 2003) and evergreen oaks (work in progress).

Combination of variants in the 23 polymorphic fragments has led to the definition of 81 different haplotypes (description of haplotypes is shown in Appendix A1). The minimum length spanning network obtained for the pool of samples (Figure 1) reflects the relationships between them. As expected in such complex data, some homoplasy may occur. In fact, connections to central haplotypes through missing ones present some uncertainty (ie haplotypes 7, 67, 72). Despite the possible homoplasy, the existence of two peripheral

Table 3 Polymorphic fragments and their variants

\begin{tabular}{|c|c|}
\hline Polymorphic fragments & Size of the variants (bp) \\
\hline DT-Taq1 & $753(1), 722(2), 699(3), 669(4), 558+109(9)^{a}$ \\
\hline DT-Taq3 & $361(1), 358(2)$, a $349(3), 335(4), 331(5)$ \\
\hline DT-Taq4 & $225(1), 223(2), 217(3)$ \\
\hline CD-Taq1 & $1743(1), 1307(2), 942(3), 891(4)^{a}$ \\
\hline CD-Taq2 & $833(1), 780(2)$ \\
\hline CD-Taq3 & 523(1), 512(2), 506(3) ${ }^{\mathrm{b}}$ \\
\hline CD-Taq6 & 277(1), 269(2), 202+66(9), absent in Q. suber \\
\hline CD-Taq10 & $70(1), 57(2), 43(3)^{b}$ \\
\hline AS-Hinf1 & $852(1), 806(2), 771(3), 767(4)^{\mathrm{b}}$ \\
\hline AS-Hinf2 & $611(1), \mathbf{5 7 8 ( 2 )}$ \\
\hline AS-Hinf3 & $577(1), 512(2), 597-75(0)$ \\
\hline AS-Hinf4 & $473(1), 457(2), 412(3)$ \\
\hline AS-Hinf6 & 299(1), 291(2), 268(3), 261(4), 254(5), 240(6) \\
\hline AS-Hinf8 & 183(1), 114(2) \\
\hline SR-Hinf1 & $578(1), \mathbf{5 2 8 ( 2 )}$ \\
\hline SR-Hinf2 & $335(1), 326(2)$, , $324(3), \mathrm{b} 317(4), 421-132(0)$ \\
\hline SR-Hinf3 & $316(1), 307(2), 296(3)$ \\
\hline SR-Hinf4 & $296(1), 293(2), 288(3), 286(4), 185+115(9)^{\mathrm{b}}$ \\
\hline SR-Hinf5 & $268(1), 263(2), 241(3)$, b $228(4)$, , $520-202(0)$ \\
\hline TF-Hinf1 & $487(1)$, b $479(2)$, a $468(3)$ \\
\hline TF-Hinf3 & $278(1), 270(2), 266(3)^{\mathrm{b}}$ \\
\hline TF-Hinf4 & $268(1), 261(2), 254(3), 249(4))^{\mathrm{b}} 243(5)^{\mathrm{a}}$ \\
\hline TF-Hinf5 & $263(1), 163+74(9)$ \\
\hline
\end{tabular}

Number in parentheses indicates the code of each one. The most frequent variant for each fragment is in bold.

${ }^{a}$ Variants restricted to ilex-coccifera II type.

bVariants restricted to suber type.

Table 2 PCR and digestion conditions

\begin{tabular}{lll}
\hline Fragment/enzyme & PCR conditions & Digestion \\
\hline DT/TaqI & $\left.94^{\circ} \mathrm{C} 45 \mathrm{~s} / 58^{\circ} \mathrm{C} 4 \mathrm{~min} / 72^{\circ} \mathrm{C} 2 \mathrm{~min}\right] \times 30$ cycles & $65^{\circ} \mathrm{C} 3-4 \mathrm{~h}$ \\
CD/TaqI & $\left.94^{\circ} \mathrm{C} 45 \mathrm{~s} / 54.5^{\circ} \mathrm{C} 45 \mathrm{~s} / 72^{\circ} \mathrm{C} 2 \mathrm{~min}\right] \times 30 \mathrm{cycles}$ & $65^{\circ} \mathrm{C} 3-4 \mathrm{~h}$ \\
AS/HinfI & $\left.94^{\circ} \mathrm{C} 45 \mathrm{~s} / 57^{\circ} \mathrm{C} 4 \mathrm{~min} / 72^{\circ} \mathrm{C} 2 \mathrm{~min}\right] \times 37$ cycles & $37^{\circ} \mathrm{C} \mathrm{O} / \mathrm{N}$ \\
SR/HinfI & $\left.94^{\circ} \mathrm{C} 45 \mathrm{~s} / 56^{\circ} \mathrm{C} 2 \mathrm{~min} / 72^{\circ} \mathrm{C} 2 \mathrm{~min}\right] \times 30$ cycles & $37^{\circ} \mathrm{C} \mathrm{O} / \mathrm{N}$ \\
TF/HinfI & $\left.94^{\circ} \mathrm{C} 45 \mathrm{~s} / 56^{\circ} \mathrm{C} 2 \mathrm{~min} / 72^{\circ} \mathrm{C} 2 \mathrm{~min}\right] \times 30$ cycles & $37^{\circ} \mathrm{C} \mathrm{O} / \mathrm{N}$ \\
\hline
\end{tabular}




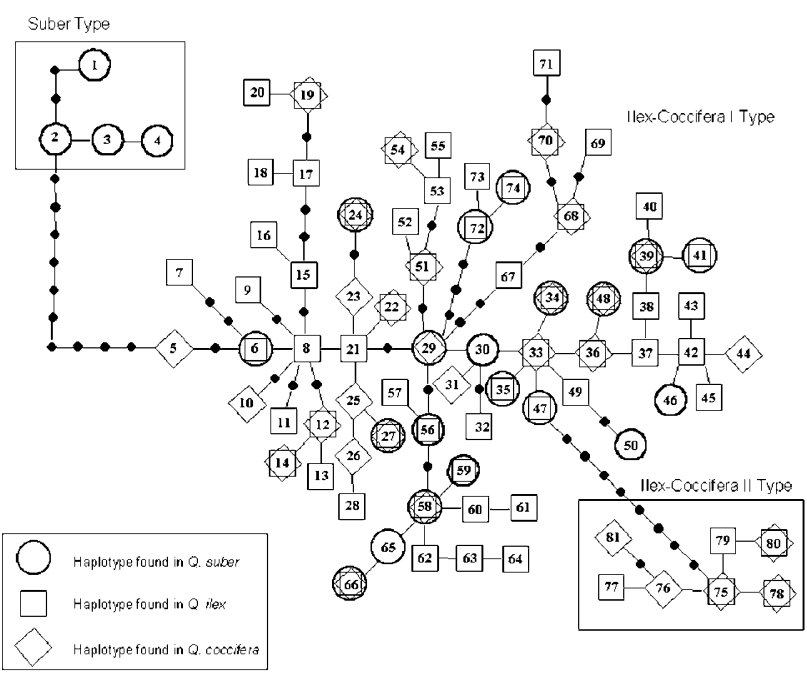

Figure 1 Minimum spanning network of the 81 haplotypes present in the three species. Black dots represent missing or unsampled haplotypes.

groups of haplotypes with a large distance (9 and 12 mutations, respectively) from the main cluster and without intermediate types is clear. As the geographic survey is very extensive, with no important gaps, we consider that these three groups represent divergent lineages: suber type (for $\mathrm{H} 1-\mathrm{H} 4$, occurring exclusively in Q. suber individuals), ilex-coccifera $I(\mathrm{H} 5-\mathrm{H} 74)$ and ilexcoccifera II (H75-H81) types. Separation between species is not complete, because about $40 \%$ of $Q$. suber populations show the ilex-coccifera I type, and $Q$. coccifera share most of haplotypes with $Q$. ilex. No $Q$. ilex or $Q$. coccifera trees show the suber type and no $Q$. suber show the ilexcoccifera II type (haplotype frequencies for each species is shown in Appendix A1).

Differences between the suber and ilex-coccifera I and II types are due to the number of polymorphic restriction fragments and to the amount and length of variants in each. Five polymorphic fragments were identified for the suber type, each showing two length variants. Alternatively, for the ilex-coccifera I type there were 22 variable fragments, and six for the ilex-coccifera II type. As a consequence, the number of haplotypes generated for the ilex-coccifera I type (70) is significantly higher than the one for the suber type (4) or for the ilex-coccifera II type (7).

\section{Discussion}

The present study documents cpDNA variation in five widely used chloroplast fragments in the three main evergreen Quercus species of the Western Mediterranean range. Four of these fragments have been analysed using the same technique in other European Quercus species (Petit et al, 2002), so comparison between the results can be performed. Restriction patterns are quite different in deciduous and in evergreen Quercus (Petit et al, 2002) and no common haplotypes for both groups have been detected. When comparing the interspecific cpDNA variation of both groups, an extensive sharing of cpDNA haplotypes was noted between deciduous Quercus species (Petit et al, 2002).
Our haplotype network for evergreen Quercus (Figure 1) indicates the existence of three groups, one of which can be considered as specific of $Q$. suber. Within this lineage, haplotypes 2-4 are very close, while haplotype 1 has diverged by two mutations from them. This one is the most frequent haplotype found in $Q$. suber, with an Iberian-Moroccan distribution (the most intensively sampled area), and it is separated from the Middle Mediterranean range, where haplotypes 2-4 occur (data in preparation). The network also shows the mean pairwise distance between suber and the two ilex-coccifera lineages. This result confirms the work of Manos et al (1999) on the phylogeny of the genus with nuclear and chloroplast markers, and of Belahbib et al (2001) on the phylogeography of $Q$. ilex and $Q$. suber in Morocco. Both report the separation between the two taxa. However, our data point out that these lineages do not completely correspond with a separation between species, as some of the $Q$. suber samples occur in ilexcoccifera types. Asymmetry is evident, since no $Q$. ilex shows a suber haplotype, in contrast to the extensive sharing found in deciduous oaks. Haplotype sharing between $Q$. suber and $Q$. ilex has also been reported for Moroccan sympatric populations (Belahbib et al, 2001) and it is interpreted by the authors as interspecific genetic exchanges. In the present work, the absence in $Q$. suber of haplotypes from the divergent ilex-coccifera II type is noteworthy, even though some mixed populations were sampled in the regions where this lineage appears. Further research should clarify this point, as well as the existence of some limits to interspecific exchange.

Hybridisation between $Q$. ilex and $Q$. suber occurs in nature, although it is not a frequent event. Capture of unexpected chloroplast haplotypes by hybridisation and introgression has been proposed as the most likely explanation for the sharing of cytoplasmic genes both in deciduous and evergreen oaks (Belahbib et al, 2001; Petit et al, 2002) as well as in other species (Smith and Sytsma, 1990; Palmé and Vendramin, 2002). Asymmetric hybridisation has been confirmed by Boavida et al (2001), who described postpollination barriers in $Q$. suber to interspecific crosses with $Q$. ilex, $Q$. coccifera, $Q$. faginea and $Q$. robur. These authors also report higher success rate in the interspecific crosses for $Q$. suber acting as pollen donor rather than as female parent due to differential growth of the pollen tubes of both species. Phenological differences also favour this direction of hybridisation (Varela and Valdiviesso, 1995; Elena-Rosselló and de la Cruz, 1998). Since both species are protandrous and $Q$. ilex flowers earlier, early cork oak male flowers can pollinate late female holm oaks. This interpretation is supported by the discovery of ilex-coccifera $I$ haplotypes in $Q$. suber individuals, and the absence of the opposite situation.

No such data are available for $Q$. coccifera; so, in spite of the presence of some common haplotypes, no mechanism for introgression with $Q$. suber can be confirmed. On the other hand, almost complete sharing of haplotypes between $Q$. ilex and $Q$. coccifera has been observed, which could be due to an incomplete lineage sorting or hybridisation, which may occur in the same way as in deciduous Quercus (Petit et al, 2002) since no particular $Q$. coccifera lineage has been found.

The presence of possible homoplasy would mainly have an effect in the ilex-coccifera I lineage where the high 
number of haplotypes confuses the relationships between them, and causes difficulty in the recognition of subgroups. However, it does not affect the divergence between ilex-coccifera I and II lineages. This divergence is also clear in the geographic distribution of each lineage: lineage $I$ is found in the Iberian Peninsula, southern France and Morocco, while lineage $I I$ is restricted to the Central Mediterranean Basin and some points of southeastern Spain and Balearic Islands (data in preparation). Lineage II would correspond to the cytotypes 3-10 described by Lumaret et al (2002) for Q. ilex using classic RFLPs.

The strong haplotypic richness obtained for ilexcoccifera I type is remarkable, since it is much higher than levels previously reported for other species of the genus (Petit et al, 2002; Olalde et al, 2002). Considering the low mutation rate reported for the chloroplast genome (Wolfe et al, 1987; Provan et al, 1999), the high diversity found, particularly in Iberian $Q$. ilex (ilexcoccifera $I$ ), is most likely explained by the ancient presence of the species, which would have allowed the accumulation of this high number of mutations. Furthermore, glaciations might not have involved the extinction of most haplotypes, as the persistence of numerous populations is possible. A similar situation is found in Asian stone oaks (Lithocarpus) (Cannon and Manos, 2003), which show a high level of chloroplast sequence variation, explained by the authors as a result of the continuous presence of populations in southeast Asia. This could be the case for $Q$. ilex and, to a lesser extent, $Q$. coccifera, which is able to inhabit very different ecosystems due to their great plasticity (Barbero et al, 1992). In addition, their ability to resprout after a major perturbation could favour the persistence of the species when climatic conditions are worse, and therefore the maintenance of strong cpDNA variation. Conversely, the thermophilous character and strict soil requirements of $Q$. suber (it can only live in acid or decarbonated soils) make it less resilient to strong environmental changes and probably caused a great range reduction during glacial ages.

In conclusion, these new data, along with previous reports, indicate that evergreen Mediterranean oaks present remarkable levels of cpDNA variation, sometimes due to interspecific hybridisation. Our results suggest that the action of several factors (interspecific exchanges, population size fluctuations, migration) have caused complex evolutionary histories. Differences in cytoplasmic variability are also found between $Q$. suber and $Q$. ilex-Q. coccifera, which are interpreted as a consequence of their different responses to environmental changes. Future work should focus on discerning the geographic structure of this variation to study the history of the species in depth. Chloroplast and nuclear data should also be compared in order to assess the possible reflection of cytoplasmic introgression in the nuclear genome, as well as the correspondence between both kinds of marker.

\section{Acknowledgements}

This work was supported by Dirección General de Conservación de la Naturaleza (Ministerio de Medio Ambiente, Spain) project: 'Evaluation and conservation of genetic resources of Mediterranean sclerophyllous
Quercus in Spain', by the Spanish Ministerio de Ciencia y Tecnología (grant REN2000-1716/GLO). Unai Lopez-deHeredia has a PhD grant of the Spanish Ministerio de Educacion, Cultura y Deporte. We thank Prof. GM Hewitt, Drs PG Goicoechea, R Alía and A Soto for their valuable suggestions in discussion and for an early review of the paper, and to two anonymous reviewers for their comments to improve the manuscript.

\section{References}

Barbero M, Loisel R, Quezel P (1992). Biogeography, ecology and history of Quercus ilex ecosystems in Mediterranean region. Vegetatio 99-100: 14-19.

Belahbib N, Pemonge M-H, Ouassou A, Sbay H, Kremer A, Petit RJ (2001). Frequent cytoplasmic exchanges between oak species that are not closely related: Quercus suber and $Q$. ilex in Morocco. Mol Ecol 10: 2003-2012.

Boavida LC, Silva JP, Feij JA (2001). Sexual reproduction in the cork oak (Quercus suber L.). II. Crossing intra- and interspecific barriers. Sex Plant Reprod 14: 143-152.

Cannon CH, Manos PS (2003). Phylogeography of the Southeast Asian stone oaks (Lithocarpus). J Biogeogr 30: 211-226.

Deguilloux MF, Dumolin-Lapègue S, Gielly L, Grivet D, Petit RJ (2003). A set of primers for the amplification of chloroplast microsatellites in Quercus. Mol Ecol Notes 3: 24-27.

Demesure B, Sodzi N, Petit RJ (1995). A set of universal primers for amplification of polymorphic non-coding regions of mitochondrial and chloroplast DNA in plants. Mol Ecol 4: 129-131.

Doyle JJ, Doyle JL (1990). Isolation of plant DNA from fresh tissue. Focus 12: 13-15.

Dumolin S, Demesure B, Petit RJ (1995). Inheritance of chloroplast and mitochondrial genomes in pedunculate oak investigated with an efficient PCR method. Theor Appl Genet 91: 1253-1256.

Dumolin-Lapègue $S$, Pemonge M-H, Petit RJ (1997a). An enlarged set of consensus primers for the study of organelle DNA in plants. Mol Ecol 6: 393-397.

Dumolin-Lapègue $S$, Demesure B, Le Corre V, Fineschi S, Petit RJ (1997b). Phylogeographic structure of white oaks throughout the European continent. Genetics 146: 1475-1487.

Elena-Rosselló JA, de la Cruz PJ (1998). Levels of genetic diversity in natural, mixed populations of oak species. In Steiner KC (ed) Diversity and Adaptation in Oak Species. Proceedings of the 2nd Meeting of Working Party 2.08.05 of the IUFRO, Genetics of Quercus October 12-17, 1997, University Park, PA, USA. pp 166-171.

Excoffier L, Smouse PE (1994). Using allele frequencies and geographic subdivision to reconstruct gene trees within a species: molecular variance parsimony. Genetics 136: 343-359.

Ferris C, Oliver RP, Davy AJ, Hewitt GM (1993). Native oak chloroplasts reveal an ancient divide across Europe. Mol Ecol 2: 337-344.

Grivet D, Heinze, B, Vendramin GG, Petit RJ (2001). Genome walking with consensus primers: application to the Large Single Copy region of chloroplast DNA. Mol Ecol Notes 1: 345-349.

Lumaret R, Mir C, Michaud H, Raynal V (2002). Phylogeographical variation of chloroplast DNA in holm oak (Quercus ilex L.). Mol Ecol 11: 2327-2336.

Manos PS, Doyle JJ, Nixon C (1999). Phylogeny, biogeography and processes of molecular differentiation in Quercus subgenus Quercus (Fagaceae). Mol Phylogenet Evol 12: 333-349.

Michaud H, Toumi L, Lumaret R, Li TX, Romane F, di Giusto F (1995). Effect of geographical discontinuity on genetic variation in Quercus ilex L. (holm oak). Evidence from enzyme polymorphism. Heredity 74: 590-606. 
Olalde M, Herrán A, Espinel S, Goicoechea PG. (2002). White oaks phylogeography in the Iberian Peninsula. For Ecol Manage 156: 89-102.

Palmé AE, Vendramin GG (2002). Chloroplast DNA variation postglacial recolonization and hybridization in hazel. Corylus avellana. Mol Ecol 11: 1769-1779.

Paradis E, Strimmer K, Claude J, Noel Y, Bolker B (2003). Analysis of Phylogenetics and Evolution. URL htttp: \\www. R-Project.org.

Petit RJ, Pineau E, Demesure B, Bacilieri R, Ducousso A, Kremer A (1997). Chloroplast DNA footprints of postglacial recolonization by oaks. Proc Natl Acad Sci USA 94: 9996-10001.

Petit RJ, Csaikl UM, Bordàcs S, Burg K, Coart E, Cottrell J et al (2002). Chloroplast DNA variation in European white oaks. Phylogeography and patterns of diversity based on data from over 2600 populations. For Ecol Manage 156: 5-26.

Prim RC (1957). Shortest connection networks and some generalizations. Bell System Tech J 36: 1389-1401.

Provan J, Soranzo N, Wilson NJ, Goldstein DB, Powell W (1999). A low mutation rate for chloroplast microsatellites. Genetics 153: 943-947.

Smith RL, Sytsma KJ (1990). Evolution of Populus nigra (Sect. Aigeiros): introgressive hybridization and the chloroplast contribution of Populus alba (Sect. Leuce). Am J Bot 77: 11761187.
Taberlet P, Gielly L, Patou G, Bouvet J (1991). Universal primers for amplification of three non-coding regions of chloroplast DNA. Plant Mol Biol 17: 1105-1109.

Toumi L, Lumaret R (1998). Genetic variation at allozyme loci in cork-oak (Quercus suber L.): the role of phylogeography and genetic introgression by other Mediterranean oak species and human activities. Theor Appl Genet 97: 647-656.

Toumi L, Lumaret R (2001). Allozyme characterisation of four Mediterranean evergreen oak species. Biochem Syst Ecol 29: 799-817.

Varela MC, Valdiviesso T (1995). Phenological phases of Quercus suber L. flowering. For Genet 3: 93-102.

Whittemore AT, Schaal BA (1991). Interespecific gene flow in oaks. Proc Natl Acad Sci USA 88: 2540-2544.

Wolfe KH, Li WH, Sharp PM (1987). Rates of nucleotide substitution vary greatly among plant mitochondrial, chloroplast and nuclear DNA. Proc Natl Acad Sci USA 84: 90549058.

\section{Appendix A1}

A description of haplotypes is presented in Table A1.

Table A1 Haplotypes detected in the survey

\begin{tabular}{|c|c|c|c|c|c|c|c|c|c|c|c|c|c|c|c|c|c|c|c|c|c|c|c|c|c|c|}
\hline \multirow[t]{2}{*}{ Hapl } & \multicolumn{3}{|c|}{$D T$-Taq $I$} & \multicolumn{5}{|c|}{$C D$-Taq $I$} & \multicolumn{6}{|c|}{ AS-Hinf1 } & \multicolumn{5}{|c|}{ SR-Hinf1 } & \multicolumn{4}{|c|}{ TF-Hinf1 } & \multicolumn{3}{|c|}{ Frequency } \\
\hline & 1 & 3 & 4 & 1 & 2 & 3 & 6 & 10 & 1 & 2 & 3 & 4 & 6 & 8 & 1 & 2 & 3 & 4 & 5 & 1 & 3 & 4 & 5 & Qs & $Q i$ & $Q_{c}$ \\
\hline 1 & 4 & 1 & 2 & 4 & 2 & 3 & 0 & 3 & 3 & 2 & 1 & 1 & 2 & 2 & 2 & 2 & 3 & 9 & 3 & 1 & 3 & 4 & 9 & 58.91 & 0 & 0 \\
\hline 2 & 4 & 1 & 2 & 3 & 2 & 3 & 0 & 3 & 4 & 2 & 1 & 1 & 2 & 2 & 2 & 2 & 3 & 9 & 4 & 1 & 3 & 4 & 9 & 0.81 & 0 & 0 \\
\hline 3 & 4 & 1 & 2 & 3 & 2 & 3 & 0 & 3 & 3 & 2 & 1 & 1 & 2 & 2 & 2 & 3 & 3 & 9 & 4 & 1 & 3 & 4 & 9 & 5.70 & 0 & 0 \\
\hline 4 & 4 & 1 & 2 & 3 & 2 & 3 & 0 & 3 & 3 & 2 & 1 & 1 & 2 & 2 & 2 & 3 & 3 & 9 & 4 & 1 & 3 & 4 & 9 & 6.64 & 0 & 0 \\
\hline 5 & 3 & 1 & 2 & 3 & 2 & 1 & 1 & 2 & 2 & 2 & 1 & 3 & 6 & 2 & 2 & 2 & 3 & 2 & 4 & 3 & 1 & 2 & 9 & 0 & 0 & 2.49 \\
\hline 6 & 3 & 1 & 2 & 3 & 2 & 1 & 1 & 2 & 2 & 2 & 1 & 3 & 5 & 2 & 2 & 2 & 3 & 2 & 1 & 3 & 1 & 2 & 9 & 0 & 2.24 & 0 \\
\hline 7 & 4 & 3 & 2 & 3 & 2 & 1 & 1 & 2 & 2 & 2 & 1 & 3 & 5 & 2 & 2 & 2 & 3 & 2 & 0 & 3 & 1 & 2 & 9 & 0.12 & 0 & 0 \\
\hline 8 & 3 & 1 & 2 & 2 & 2 & 1 & 1 & 2 & 2 & 2 & 1 & 3 & 5 & 2 & 2 & 2 & 3 & 2 & 1 & 3 & 1 & 2 & 9 & 0 & 0.63 & 0 \\
\hline 9 & 2 & 1 & 2 & 2 & 2 & 1 & 1 & 2 & 2 & 2 & 1 & 3 & 5 & 2 & 2 & 2 & 3 & 2 & 0 & 3 & 1 & 2 & 9 & 0 & 0.89 & 0 \\
\hline 10 & 3 & 4 & 2 & 2 & 2 & 1 & 1 & 2 & 2 & 2 & 1 & 3 & 5 & 2 & 2 & 1 & 3 & 2 & 1 & 3 & 1 & 2 & 9 & 0 & 0.63 & 0 \\
\hline 11 & 3 & 4 & 2 & 2 & 2 & 1 & 1 & 2 & 2 & 2 & 1 & 3 & 5 & 2 & 2 & 2 & 3 & 2 & 4 & 3 & 1 & 2 & 9 & 0 & 0 & 1.25 \\
\hline 12 & 4 & 1 & 2 & 2 & 2 & 1 & 1 & 2 & 2 & 2 & 1 & 3 & 4 & 2 & 2 & 2 & 3 & 2 & 1 & 3 & 1 & 2 & 9 & 0 & 0.09 & 0 \\
\hline 13 & 4 & 1 & 2 & 2 & 2 & 1 & 1 & 2 & 2 & 2 & 1 & 3 & 4 & 2 & 2 & 2 & 3 & 1 & 1 & 3 & 1 & 2 & 0 & 0 & 2.95 & 0.75 \\
\hline 14 & 4 & 1 & 2 & 2 & 2 & 1 & 1 & 2 & 2 & 2 & 1 & 3 & 4 & 2 & 2 & 2 & 3 & 3 & 1 & 3 & 1 & 2 & 9 & 0 & 0.45 & 0 \\
\hline 15 & 3 & 5 & 2 & 2 & 2 & 1 & 1 & 2 & 2 & 2 & 1 & 3 & 5 & 1 & 2 & 2 & 3 & 2 & 1 & 3 & 1 & 2 & 9 & 0.81 & 0.54 & 0 \\
\hline 16 & 3 & 5 & 2 & 2 & 2 & 1 & 1 & 2 & 2 & 2 & 1 & 3 & 5 & 1 & 2 & 2 & 3 & 1 & 1 & 3 & 1 & 2 & 9 & 0 & 0.09 & 0 \\
\hline 17 & 3 & 5 & 2 & 2 & 2 & 1 & 1 & 2 & 2 & 1 & 2 & 3 & 4 & 1 & 2 & 2 & 3 & 2 & 1 & 3 & 1 & 2 & 9 & 0 & 2.15 & 0 \\
\hline 18 & 3 & 1 & 2 & 2 & 2 & 1 & 1 & 2 & 2 & 1 & 2 & 3 & 4 & 1 & 2 & 2 & 3 & 2 & . & 3 & 1 & 2 & 9 & 0 & 0.27 & 0 \\
\hline 19 & 3 & 5 & 2 & 2 & 2 & 1 & 1 & 1 & 2 & 1 & 2 & 3 & 4 & 1 & 2 & 2 & 3 & 2 & 2 & 3 & 1 & 2 & 9 & 0 & 0.09 & 0 \\
\hline 20 & 3 & 5 & 2 & 2 & 2 & 1 & 1 & 1 & 2 & 1 & 2 & 3 & 4 & 1 & 2 & 2 & 3 & 2 & 2 & 3 & 1 & 1 & 9 & 0 & 4.92 & 2.00 \\
\hline 21 & 3 & 3 & 2 & 2 & 2 & 1 & 1 & 2 & 2 & 2 & 1 & 3 & 5 & 2 & 2 & 2 & 3 & 2 & 1 & 3 & 1 & 2 & 9 & 0 & 0.89 & 0 \\
\hline 22 & 3 & 3 & 2 & 2 & 2 & 1 & 1 & 2 & 2 & 2 & 1 & 3 & 6 & 2 & 2 & 2 & 3 & 2 & 1 & 3 & 1 & 2 & 9 & 0 & 0.45 & 0 \\
\hline 23 & 3 & 3 & 2 & 2 & 2 & 1 & 1 & 2 & 2 & 2 & 1 & 3 & 5 & 2 & 2 & 2 & 2 & 2 & 1 & 3 & 1 & 2 & 9 & 0.35 & 8.05 & 6.73 \\
\hline 24 & 3 & 3 & 3 & 2 & 2 & 1 & 1 & 2 & 2 & 2 & 1 & 3 & 1 & 2 & 2 & 2 & 2 & 2 & 1 & 3 & 1 & 2 & 9 & 0 & 0 & 0.50 \\
\hline 25 & 3 & 3 & 2 & 2 & 2 & 1 & 1 & 2 & 2 & 2 & 1 & 3 & 5 & 2 & 2 & 2 & 3 & 1 & 1 & 3 & 1 & 2 & 9 & 0.70 & 3.49 & 3.49 \\
\hline 26 & 3 & 3 & 2 & 2 & 2 & 1 & 9 & 2 & 2 & 2 & 1 & 3 & 5 & 2 & 2 & 2 & 3 & 1 & 1 & 3 & 1 & 2 & 9 & 0.35 & 0 & 1.25 \\
\hline 27 & 2 & 3 & 2 & 2 & 2 & 1 & 1 & 2 & 2 & 2 & 1 & 3 & 5 & 2 & 2 & 2 & 3 & 1 & 1 & 3 & 1 & 2 & 9 & 0 & 0 & 1.75 \\
\hline 28 & 2 & 3 & 2 & 2 & 2 & 1 & 9 & 2 & 2 & 2 & 1 & 3 & 5 & 2 & 2 & 2 & 3 & 1 & 1 & 3 & 1 & 2 & 9 & 1.16 & 0.27 & 1.25 \\
\hline 29 & 2 & 3 & 2 & 2 & 2 & 1 & 1 & 2 & 2 & 2 & 1 & 3 & 4 & 2 & 2 & 2 & 3 & 2 & 1 & 3 & 1 & 2 & 9 & 0 & 0.27 & 0 \\
\hline 30 & 2 & 3 & 2 & 2 & 2 & 1 & 1 & 2 & 2 & 2 & 1 & 3 & 4 & 2 & 2 & 4 & 3 & 2 & 1 & 3 & 1 & 2 & 9 & 2.10 & 0 & 0 \\
\hline 31 & 2 & 3 & 2 & 2 & 2 & 1 & 1 & 2 & 2 & 2 & 1 & 3 & 4 & 2 & 2 & 4 & 3 & 2 & 2 & 3 & 1 & 2 & 9 & 0.23 & 0 & 0 \\
\hline 32 & 2 & 1 & 2 & 2 & 2 & 1 & 1 & 2 & 2 & 2 & 1 & 3 & 4 & 2 & 2 & 4 & 3 & 2 & 4 & 3 & 1 & 2 & 9 & 0 & 0 & 2.49 \\
\hline 33 & 3 & 3 & 2 & 2 & 2 & 1 & 1 & 2 & 2 & 2 & 1 & 3 & 4 & 2 & 2 & 4 & 3 & 2 & 1 & 3 & 1 & 2 & 9 & 0 & 0.09 & 0 \\
\hline 34 & 3 & 3 & 1 & 2 & 2 & 1 & 1 & 2 & 2 & 2 & 1 & 3 & 4 & 2 & 2 & 4 & 3 & 2 & 1 & 3 & 1 & 2 & 9 & 0 & 0.36 & 8.48 \\
\hline 35 & 3 & 3 & 2 & 3 & 2 & 1 & 1 & 2 & 2 & 2 & 1 & 3 & 4 & 2 & 2 & 4 & 3 & 2 & 1 & 3 & 1 & 2 & 9 & 0.23 & 0.45 & 1.25 \\
\hline 36 & 3 & 3 & 2 & 2 & 2 & 1 & 1 & 2 & 2 & 2 & 2 & 3 & 4 & 2 & 2 & 4 & 3 & 2 & 1 & 3 & 1 & 2 & 9 & 1.63 & 0.36 & 0 \\
\hline 37 & 3 & 3 & 2 & 2 & 2 & 1 & 1 & 2 & 2 & 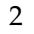 & 2 & 3 & 4 & 2 & 2 & 1 & 3 & 2 & 7 & 3 & 1 & 2 & 9 & 0 & 8.05 & 10.97 \\
\hline 38 & 3 & 3 & 2 & 2 & 2 & 1 & 1 & 2 & 2 & 2 & 2 & 3 & 4 & 2 & 1 & 1 & 3 & 2 & 1 & 3 & 1 & 2 & 9 & 0 & 0.27 & 0 \\
\hline 39 & 2 & 3 & 2 & 2 & 2 & 1 & 1 & 2 & 2 & 2 & 2 & 3 & 4 & 2 & 1 & 1 & 3 & 2 & 1 & 3 & 1 & 2 & 9 & 0 & 0.09 & 0 \\
\hline 40 & 2 & 3 & 2 & 2 & 2 & 1 & 1 & 2 & 2 & 2 & 2 & 3 & 3 & 2 & 1 & 1 & 3 & 2 & 1 & 3 & 1 & 2 & 9 & 0.12 & 6.35 & 3.24 \\
\hline
\end{tabular}


Table A1 Continued

\begin{tabular}{|c|c|c|c|c|c|c|c|c|c|c|c|c|c|c|c|c|c|c|c|c|c|c|c|c|c|c|}
\hline \multirow[t]{2}{*}{ Hapl } & \multicolumn{3}{|c|}{ DT-TaqI } & \multicolumn{5}{|c|}{ CD-Taq $I$} & \multicolumn{6}{|c|}{$A S$-Hinf1 } & \multicolumn{5}{|c|}{$S R-H i n f 1$} & \multicolumn{4}{|c|}{$T F-$ Hinf1 } & \multicolumn{3}{|c|}{ Frequency } \\
\hline & 1 & 3 & 4 & 1 & 2 & 3 & 6 & 10 & 1 & 2 & 3 & 4 & 6 & 8 & 1 & 2 & 3 & 4 & 5 & 1 & 3 & 4 & 5 & Qs & $Q i$ & $Q c$ \\
\hline 41 & 2 & 3 & 2 & 2 & 2 & 1 & 1 & 2 & 2 & 2 & 2 & 3 & 4 & 2 & 1 & 1 & 3 & 1 & 1 & 3 & 1 & 2 & 9 & 0 & 0.09 & 0 \\
\hline 42 & 3 & 3 & 2 & 2 & 2 & 1 & 1 & 2 & 2 & 2 & 2 & 2 & 4 & 2 & 2 & 1 & 3 & 2 & 1 & 3 & 1 & 2 & 9 & 1.05 & 0.72 & 0 \\
\hline 43 & 1 & 3 & 2 & 2 & 2 & 1 & 1 & 2 & 2 & 2 & 2 & 2 & 4 & 2 & 2 & 1 & 3 & 2 & 1 & 3 & 1 & 2 & 9 & 0 & 0.18 & 0 \\
\hline 44 & 3 & 3 & 2 & 2 & 2 & 1 & 1 & 2 & 2 & 2 & 2 & 2 & 4 & 2 & 2 & 1 & 3 & 2 & 4 & 3 & 1 & 2 & 9 & 0 & 0.09 & 0 \\
\hline 45 & 3 & 3 & 2 & 2 & 2 & 1 & 1 & 2 & 2 & 2 & 2 & 2 & 4 & 2 & 2 & 2 & 3 & 2 & 1 & 3 & 1 & 2 & 9 & 0 & 0 & 2.00 \\
\hline 46 & 2 & 3 & 2 & 2 & 2 & 1 & 1 & 2 & 2 & 2 & 2 & 2 & 4 & 2 & 2 & 1 & 3 & 2 & 1 & 3 & 1 & 2 & 9 & 0 & 0.89 & 0 \\
\hline 47 & 3 & 3 & 2 & 2 & 2 & 1 & 1 & 2 & 2 & 2 & 1 & 3 & 4 & 2 & 2 & 4 & 3 & 1 & 1 & 3 & 1 & 2 & 9 & 1.51 & 0 & 0 \\
\hline 48 & 3 & 3 & 2 & 2 & 2 & 1 & 1 & 2 & 2 & 2 & 2 & 3 & 4 & 2 & 2 & 4 & 3 & 1 & 1 & 3 & 1 & 2 & 9 & 0.47 & 0.98 & 0 \\
\hline 49 & 3 & 3 & 2 & 2 & 2 & 1 & 1 & 2 & 2 & 2 & 1 & 2 & 4 & 2 & 2 & 4 & 3 & 2 & 1 & 3 & 1 & 2 & 9 & 1.16 & 2.86 & 4.99 \\
\hline 50 & 3 & 3 & 2 & 2 & 2 & 1 & 2 & 2 & 2 & 2 & 2 & 2 & 4 & 2 & 2 & 4 & 3 & 2 & 1 & 3 & 1 & 2 & 9 & 0 & 0.18 & 0 \\
\hline 51 & 2 & 3 & 2 & 3 & 2 & 1 & 1 & 2 & 2 & 2 & 1 & 3 & 4 & 2 & 2 & 2 & 3 & 2 & 1 & 3 & 2 & 2 & 9 & 0.23 & 0 & 0 \\
\hline 52 & 3 & 3 & 2 & 3 & 2 & 1 & 1 & 2 & 2 & 2 & 1 & 3 & 4 & 2 & 2 & 2 & 3 & 2 & 1 & 3 & 2 & 2 & 9 & 0 & 4.11 & 2.74 \\
\hline 53 & 2 & 3 & 2 & 3 & 2 & 1 & 1 & 2 & 2 & 2 & 2 & 3 & 4 & 2 & 2 & 0 & 3 & 2 & 1 & 3 & 2 & 2 & 9 & 0 & 0.09 & 0 \\
\hline 54 & 2 & 3 & 2 & 3 & 2 & 1 & 1 & 2 & 2 & 2 & 2 & 3 & 4 & 2 & 2 & 4 & 3 & 2 & 1 & 3 & 2 & 2 & 9 & 0 & 0.89 & 0 \\
\hline 55 & 2 & 3 & 2 & 3 & 2 & 1 & 1 & 2 & 2 & 2 & 2 & 3 & 1 & 2 & 2 & 0 & 3 & 2 & 1 & 3 & 2 & 2 & 9 & 0 & 1.07 & 2.49 \\
\hline 56 & 2 & 3 & 2 & 2 & 2 & 1 & 2 & 2 & 2 & 2 & 1 & 3 & 4 & 2 & 2 & 2 & 3 & 2 & 1 & 3 & 1 & 1 & 9 & 0 & 0.09 & 0 \\
\hline 57 & 2 & 3 & 2 & 2 & 2 & 1 & 2 & 2 & 2 & 2 & 1 & 3 & 4 & 2 & 2 & 1 & 3 & 2 & 1 & 3 & 1 & 1 & 9 & 0.35 & 1.97 & 0 \\
\hline 58 & 3 & 5 & 2 & 2 & 2 & 1 & 2 & 2 & 2 & 2 & 1 & 3 & 4 & 2 & 2 & 2 & 3 & 2 & 1 & 3 & 1 & 1 & 9 & 0 & 0.18 & 0 \\
\hline 59 & 3 & 5 & 2 & 2 & 2 & 1 & 1 & 2 & 2 & 2 & 1 & 3 & 4 & 2 & 2 & 2 & 3 & 2 & 1 & 3 & 1 & 1 & 9 & 3.49 & 13.95 & 9.98 \\
\hline 60 & 3 & 5 & 2 & 2 & 2 & 1 & 2 & 2 & 2 & 2 & 1 & 3 & 4 & 2 & 2 & 1 & 3 & 2 & 1 & 3 & 1 & 1 & 9 & 0.47 & 0.18 & 0 \\
\hline 61 & 3 & 5 & 2 & 2 & 2 & 2 & 1 & 2 & 2 & 2 & 1 & 3 & 4 & 2 & 2 & 1 & 3 & 2 & 1 & 3 & 1 & 1 & 9 & 0 & 0.18 & 0 \\
\hline 62 & 3 & 4 & 2 & 2 & 2 & 1 & 2 & 2 & 2 & 2 & 1 & 3 & 4 & 2 & 2 & 2 & 3 & 2 & 1 & 3 & 1 & 1 & 9 & 0 & 0.09 & 0 \\
\hline 63 & 3 & 4 & 2 & 2 & 2 & 1 & 2 & 2 & 2 & 2 & 2 & 3 & 4 & 2 & 2 & 2 & 3 & 2 & 1 & 3 & 1 & 1 & 9 & 0 & 0.09 & 0 \\
\hline 64 & 3 & 4 & 2 & 2 & 2 & 1 & 2 & 2 & 2 & 2 & 2 & 3 & 4 & 2 & 2 & 2 & 3 & 2 & 1 & 3 & 1 & 2 & 9 & 0 & 0.09 & 0 \\
\hline 65 & 3 & 5 & 2 & 2 & 2 & 1 & 2 & 2 & 2 & 2 & 2 & 3 & 4 & 2 & 2 & 2 & 3 & 2 & 1 & 3 & 1 & 1 & 9 & 0 & 0.09 & 0 \\
\hline 66 & 3 & 5 & 2 & 2 & 2 & 1 & 2 & 2 & 2 & 2 & 2 & 2 & 4 & 2 & 2 & 2 & 3 & 2 & 1 & 3 & 1 & 1 & 9 & 0.35 & 0 & 0 \\
\hline 67 & 2 & 3 & 2 & 2 & 2 & 1 & 1 & 2 & 3 & 2 & 2 & 3 & 4 & 2 & 2 & 2 & 3 & 2 & 4 & 3 & 1 & 2 & 9 & 0.08 & 0.09 & 2.24 \\
\hline 68 & 2 & 3 & 2 & 2 & 2 & 1 & 1 & 2 & 1 & 2 & 2 & 3 & 4 & 2 & 2 & 1 & 3 & 2 & 4 & 3 & 1 & 2 & 9 & 0 & 1.16 & 0 \\
\hline 69 & 2 & 3 & 2 & 2 & 2 & 1 & 2 & 2 & 1 & 2 & 2 & 3 & 4 & 2 & 2 & 1 & 3 & 2 & 1 & 3 & 1 & 2 & 9 & 0 & 0.63 & 2.24 \\
\hline 70 & 2 & 3 & 2 & 2 & 2 & 2 & 1 & 2 & 1 & 2 & 2 & 3 & 4 & 2 & 2 & 1 & 3 & 2 & 1 & 3 & 1 & 2 & 9 & 0 & 0.18 & 0 \\
\hline 71 & 2 & 3 & 2 & 2 & 2 & 2 & 1 & 2 & 1 & 2 & 2 & 3 & 4 & 2 & 2 & 2 & 3 & 2 & 1 & 3 & 1 & 1 & 9 & 0 & 8.86 & 5.49 \\
\hline 72 & 2 & 3 & 2 & 2 & 1 & 1 & 1 & 2 & 2 & 2 & 0 & 3 & 4 & 2 & 2 & 2 & 3 & 2 & 4 & 3 & 1 & 2 & 1 & 0 & 0.36 & 0 \\
\hline 73 & 2 & 3 & 2 & 2 & 1 & 1 & 1 & 2 & 2 & 2 & 0 & 3 & 4 & 2 & 2 & 2 & 3 & 2 & 4 & 3 & 1 & 1 & 1 & 0.51 & 0.45 & 0 \\
\hline 74 & 3 & 3 & 2 & 2 & 1 & 1 & 1 & 2 & 2 & 2 & 0 & 3 & 4 & 2 & 2 & 2 & 3 & 2 & 4 & 3 & 1 & 2 & 1 & 0 & 0.09 & 0 \\
\hline 75 & 9 & 2 & 2 & 1 & 2 & 1 & 2 & 2 & 2 & 2 & 1 & 3 & 3 & 2 & 2 & 4 & 3 & 1 & 4 & 2 & 2 & 3 & 9 & 0.47 & 0.89 & 0 \\
\hline 76 & 9 & 2 & 2 & 1 & 2 & 1 & 2 & 2 & 2 & 2 & 2 & 3 & 3 & 2 & 2 & 4 & 3 & 1 & 4 & 2 & 2 & 3 & 9 & 0 & 0.27 & 9.48 \\
\hline 77 & 9 & 2 & 2 & 1 & 2 & 1 & 2 & 2 & 2 & 2 & 2 & 3 & 3 & 2 & 2 & 4 & 3 & 1 & 4 & 2 & 2 & 5 & 9 & 0 & 0 & 2.49 \\
\hline 78 & 9 & 2 & 2 & 1 & 2 & 1 & 2 & 2 & 2 & 2 & 1 & 3 & 3 & 2 & 2 & 4 & 3 & 1 & 4 & 2 & 2 & 5 & 9 & 0 & 3.67 & 0 \\
\hline 79 & 9 & 2 & 2 & 1 & 2 & 1 & 2 & 2 & 2 & 2 & 1 & 3 & 3 & 2 & 2 & 4 & 1 & 1 & 4 & 2 & 2 & 3 & 9 & 0 & 2.50 & 4.49 \\
\hline 80 & 9 & 2 & 2 & 1 & 2 & 1 & 2 & 2 & 2 & 2 & 1 & 3 & 3 & 2 & 2 & 4 & 1 & 4 & 4 & 2 & 2 & 3 & 9 & 0 & 5.10 & 0 \\
\hline 81 & 9 & 2 & 2 & 1 & 2 & 1 & 2 & 2 & 2 & 2 & 2 & 3 & 3 & 2 & 2 & 3 & 1 & 1 & 4 & 2 & 2 & 3 & 9 & 0 & 1.25 & 3.24 \\
\hline
\end{tabular}

For each haplotype, length variants (see Table 2) observed in each polymorphic fragment (DT1, DT3, etc) are listed. At the end of each line, haplotype frequency (\%) is indicated (Qs: Q. suber; Qi: Q. ilex; Qc: Q. coccifera). 